\title{
NirK and nirS Nitrite reductase genes from non-agricultural forest soil bacteria in Thailand
}

\author{
Monnat Theerachat · Chompunuch Virunanon • \\ Suphang Chulalaksananukul • Nusara Sinbuathong • \\ Warawut Chulalaksananukul
}

Received: 4 February 2010/Accepted: 28 July 2010/Published online: 10 August 2010

(C) The Author(s) 2010. This article is published with open access at Springerlink.com

\begin{abstract}
The genetic heterogeneity of the nitrite reductase gene (nirK and nirS) fragments from denitrifying prokaryotes in a non-agricultural forest soil in Thailand was investigated using soil samples from the Plant Germplasm-Royal Initiation Project area in Kanchanaburi Province, Thailand. Soil bacteria were screened for denitrification activity and 13 (from 211) positive isolates were obtained and further evaluated for their ability to reduce nitrate and to accumulate or reduce nitrite. Three species with potentially previously unreported denitrifying activities were recorded. Analysis of the partial nirK and nirS sequences of these 13 strains revealed a diverse sequence heterogeneity in these two genes within the same environment and even potentially within the same host species, the potential existence of lateral gene transfer and the first record of both nirK and nirS homologues in one bacterial species. Finally, isolates of two species of bacteria (Corynebacterium propinquum and Micrococcus lylae) are recorded as denitrifiers for the first time.
\end{abstract}

Keywords Denitrifying bacteria - Genetic diversity · Nitrite reductase gene $\cdot$ Nitrite reductase ability

M. Theerachat · C. Virunanon · W. Chulalaksananukul $(\bowtie)$ Department of Botany, Faculty of Science, Chulalongkorn University, Bangkok 10330, Thailand

e-mail: warawut.C@chula.ac.th

S. Chulalaksananukul

Department of Chemical Engineering, Faculty of Engineering, Mahidol University, Salaya Campus, Nakornpathom 73170, Thailand

N. Sinbuathong

Scientific Equipment Center, Kasetsart University Research and Development Institute, Kasetsart University, Bangkok 10900, Thailand

\section{Introduction}

Denitrification is an anaerobic process, occuring only in low-oxygen or anoxic environments and consists of four reaction steps by which nitrate is reduced to dinitrogen gas sequentially by the four metalloenzyme classes of nitrate reductases, nitrite reductases, nitric oxide reductases and nitrous oxide reductases. The nitrite reductase is the key enzyme of this respiratory process since it catalyses the reduction of soluble nitrite into gas (Zumft 1997). Two types of nitrite reductase, that differ in terms of their structure and prosthetic metal, have been characterized: a copper nitrite reductase (EC 1.7.99.3) encoded by the nirK gene and a cytochrome $c d_{1}$-nitite reductase (EC 1.7.2.1) encoded by the nirS gene that is the key enzyme and forms the distinguishing feature between denitrifiers and nitrate reducers (Henry et al. 2004).

Denitrifying microorganisms span a wide range of taxonomic groups including over 50 different genera and are not defined by a close phylogenetic relationship. Thus a phylogenetic approach involving simply the species identification, such as by the $16 \mathrm{~S}$ rRNA gene, to detect denitrifying microorganisms in the environment is not suitable (Santoro et al. 2006; Heylen et al. 2006) Therefore, an alternative approach has been to amplify denitrifying bacteria nir gene fragments by PCR amplification. To this end, degenerate nirK and nirS primers have been applied to identify denitrifiers, and to study the denitrification diversity and community structures in various environments (Braker et al. 2000; Priemé et al. 2002; Rich et al. 2003; Wang and Skipper 2004; Santoro et al. 2006; Oakley et al. 2007).

However, the research into variation and genetic analysis of the nitrite reductase genes of denitrifying bacteria in Thailand is limited, despite the diverse geochemical soil 
arrays and generally high but fragmented biodiversity in this region. In this study, the relationship between the nitrite reductase encoding genes (nirK and nirS homologs) and the in vitro ability to reduce nitrate was investigated by screening soil bacteria collected from the Plant Germplasm-Royal Initiation Project at Kanchanaburi Province, Thailand, for their denitrifying ability and then assaying for the presence of nirK and nirS homologs by PCR with degenerate primers.

\section{Materials and methods}

Denitrifying bacteria isolation and nitrite-nitrate reducing ability test

Soil samples $(500 \mathrm{~g})$ were collected at a depth of $15 \mathrm{~cm}$ below the undisturbed surface. Soil bacteria were screened and then the isolation of denitrifying bacteria was performed under anaerobic conditions by plating soil bacteria after dilution onto nutrient agar (Schalau) at $30^{\circ} \mathrm{C}$. All bacterial isolates were transferred separately into individual Durham tubes containing nitrate broth and incubated at $30^{\circ} \mathrm{C}$ for 14 days in an anaerobic chamber (Bactron/Sheldon, US). Samples from each culture were collected at day 0 and 7 , respectively. The nitrate reduction ability was analysed by using the alpha-naphthylamine method (Beishir 1996). The likely species identification of all denitrifying bacteria was performed using the API test kit according to the manufacturer's conditions (BioMerieux). Then denitrifying bacteria were cultivated in nutrient broth at $30^{\circ} \mathrm{C}$ for $18-24 \mathrm{~h}$. One $\mathrm{ml}$ of cell suspension was transferred to $150 \mathrm{ml}$ of nitrate broth and incubated in an anaerobic chamber at $30^{\circ} \mathrm{C}$ with shaking at $200 \mathrm{rev} / \mathrm{min}$ for 7 days. Nitrate and nitrite levels were measured at day 0 and 7 using a nitrate-nitrogen and nitrite-nitrogen test kit (HACH, USA), respectively, as per the manufacturer's instructions.

DNA extraction, PCR amplification, cloning, sequencing and phylogenetic analysis

Genomic DNA was extracted from the cultured bacteria as described by Ausubel et al. (2002). Fragments of the nirK and nirS genes were amplified using the primer pairs nirK1F-nirK5R for nirK and nirS1F-nirS6R for nirS (Braker et al. 1998) in a final volume of $50 \mu \mathrm{l}$ containing $5 \mu \mathrm{l}$ of $10 \times$ PCR buffer $200 \mu \mathrm{M}$ of deoxyribonucleoside triphosphate $1.0 \mathrm{U}$ of $\mathrm{Taq}$ polymerase $1 \mu \mathrm{M}$ of both primers, $400 \mathrm{ng}$ of bovine serum albumin $\mu \mathrm{l}^{-1}$ and 10-100 ng of extracted gDNA. PCR conditions consisted of $1 \mathrm{~min}$ at $95^{\circ} \mathrm{C}$, followed by a $1 \mathrm{~min}$ primer-annealing step and $1 \mathrm{~min}$ at $72^{\circ} \mathrm{C}$. After 35 cycles, a final $7 \mathrm{~min}$ incubation at $72^{\circ} \mathrm{C}$ was performed. Expected amplicons were cloned using the PCR-Script ${ }^{\mathrm{TM}}$ Amp Cloning Kit (Stratagene, USA), and transformant selection was performed according to the manufacturer's instructions. Selected transformants were then screened for the correct plasmid inserts by nested PCR, using two sets of primers (Braker et al. 1998). Plasmids were extracted from transformants that contained the desired inserts by the Fast Plasmid $^{\mathrm{TM}}$ Mini kit (Eppendorf, USA). DNA sequencing was performed commercially by pyrosequencing at Macrogen, Korea.

For each of the two gene fragments, the sequences were "blasted" and aligned by the National Center for
Table 1 Species identification, PCR amplification of nitrite reductase genes, and the percent nitrate reduction by day 7 of culture of the 13 selected isolates of denitrifying bacteria

\begin{tabular}{lllllc}
\hline Isolate & Organism & $\begin{array}{l}\text { Nitrite } \\
\text { reductase } \\
\text { gene }\end{array}$ & $\begin{array}{l}\text { \% Nitrate } \\
\text { reduction } \\
\text { by day } 7\end{array}$ & $\begin{array}{l}\text { Amount of nitrate } \\
\text { reduction (mg/l) }\end{array}$ & $\begin{array}{l}\text { Amount of nitrite } \\
\text { accumulated (mg/l) }\end{array}$ \\
\hline C22-18 & Agrobacterium radiobacter & nirK & 22.41 & 65 & 156.0 \\
C23-5 & Agrobacterium radiobacter & nirK, nirS & 46.55 & 135 & 81.1 \\
C23-15 & Agrobacterium radiobacter & nirK & 29.31 & 85 & 141.0 \\
C32-7 & Agrobacterium radiobacter & nirK & 19.64 & 55 & 173.8 \\
C32-13 & Agrobacterium radiobacter & nirK & 2.5 & 7 & 158.0 \\
C33-1 & Agrobacterium radiobacter & nirK & 21.43 & 60 & 173.3 \\
C22-14 & Burkholderia capacia & - & 58.93 & 165 & 75.0 \\
A31-18 & Corynebacterium propinquum & - & 97.32 & 171.5 & 1.18 \\
C32-5 & Micrococcus lylae & nirS & 34.48 & 100 & 137.5 \\
C32-6 & Micrococcus lylae & nirS & 56.90 & 165 & 147.2 \\
B11-3 & Pseudomonas aeruginosa & nirS & 99.14 & 287.5 & 0.2 \\
C22-5 & Pseudomonas aeruginosa & - & 62.5 & 175 & 61.2 \\
C22-24 & Pseudomonas stutzeri & - & 67.24 & 195 & 6.95 \\
Control & & & 0.00 & ND & ND \\
\hline
\end{tabular}


Biotechnology Information BLASTN program and the ClustalX programmes, respectively. Phylogenetic analysis was performed with a neighbor-joining algorithm and distance calculation according to Jukes and Cantor using PAUP4.0*b. Neisseria gonorrhoeae aniA gene (accession no. M97926) and the nir $\mathrm{N}$ gene from Pseudomonas aeruginosa (accession no. D84475) were used as out groups for nirK and nirS, respectively. The tree topology was evaluated by bootstrap analysis using 1,000 replicates. ClustalX programs, respectively. Phylogenetic analysis was performed with a neighbor-joining algorithm and distance calculation according to Jukes and Cantor using PAUP4.0*b.

Fig. 1 A rooted neighborjoining phylogram of the partial nirK sequences. The scale bar indicates the expected number of changes per sequence position. For each node, bootstrap values greater than $50 \%$ are shown. The GenBank accession number is indicated in brackets after the name of the organism. The sequence of aniA from Neisseria gonorrhoeae (accession no. M97926) was used as the out group to root the phylogram

\section{Results and discussion}

Denitrification bacteria and the nitrate-nitrite reduction ability

From the 211 soil bacteria isolates, 13 were found to be capable of denitrification and were then evaluated for the ability to reduce nitrate, and to accumulate or reduce nitrite according to the method described by Wistreich and Lechtman (1988). These 13 bacterial isolates with denitrifying activity were classified as six species by the API test results (Table 1). API kit was selected primarily to

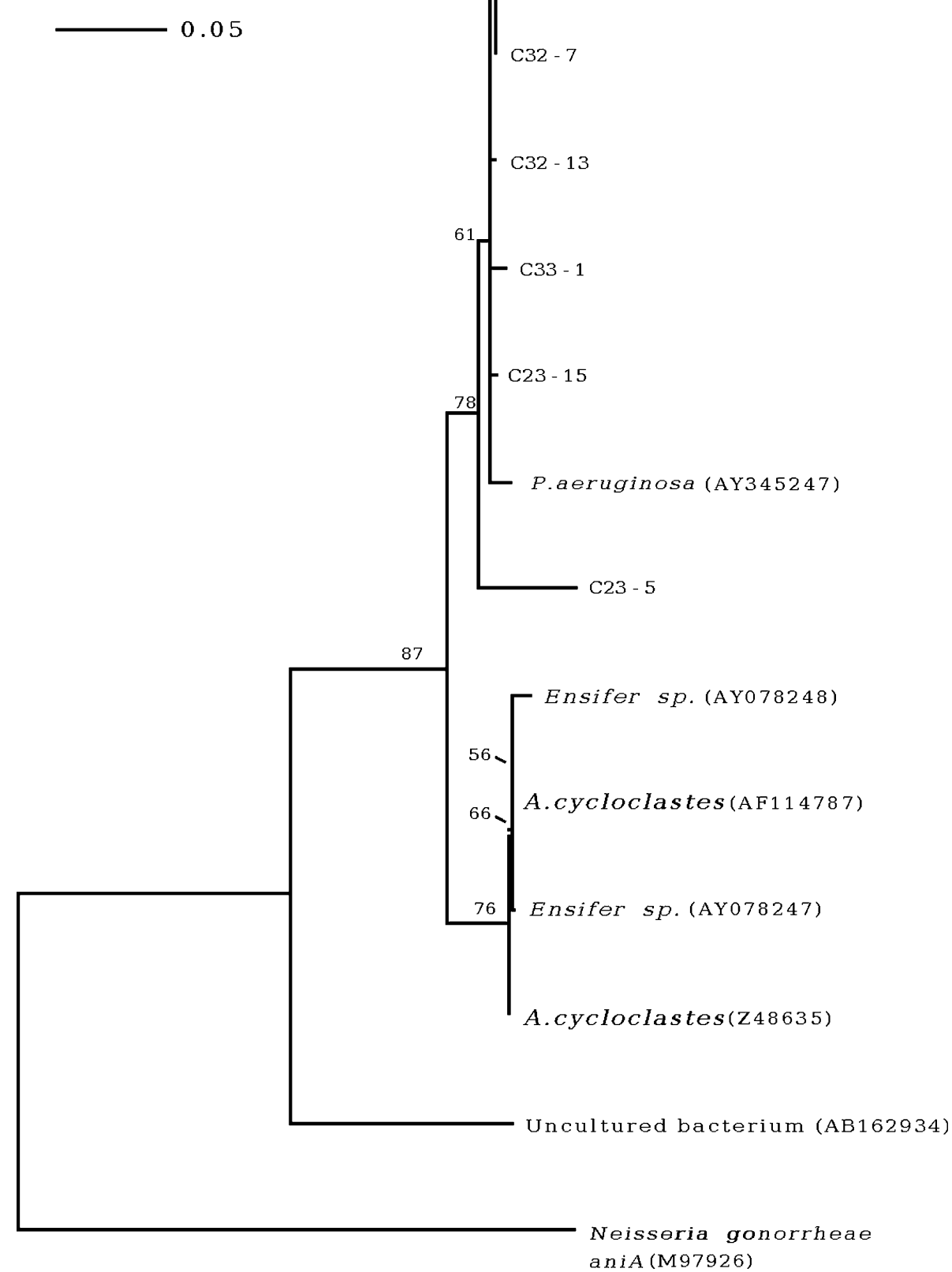


Fig. 2 A rooted neighborjoining phylogram of the partial nirS sequences. The scale bar indicates the expected number of changes per sequence position. For each node, bootstrap values greater than $50 \%$ are shown. The GenBank accession number is indicated in brackets after the name of the organism. The sequence of nirN from Pseudomonas aeruginosa was used as the out-group to root the phylogram

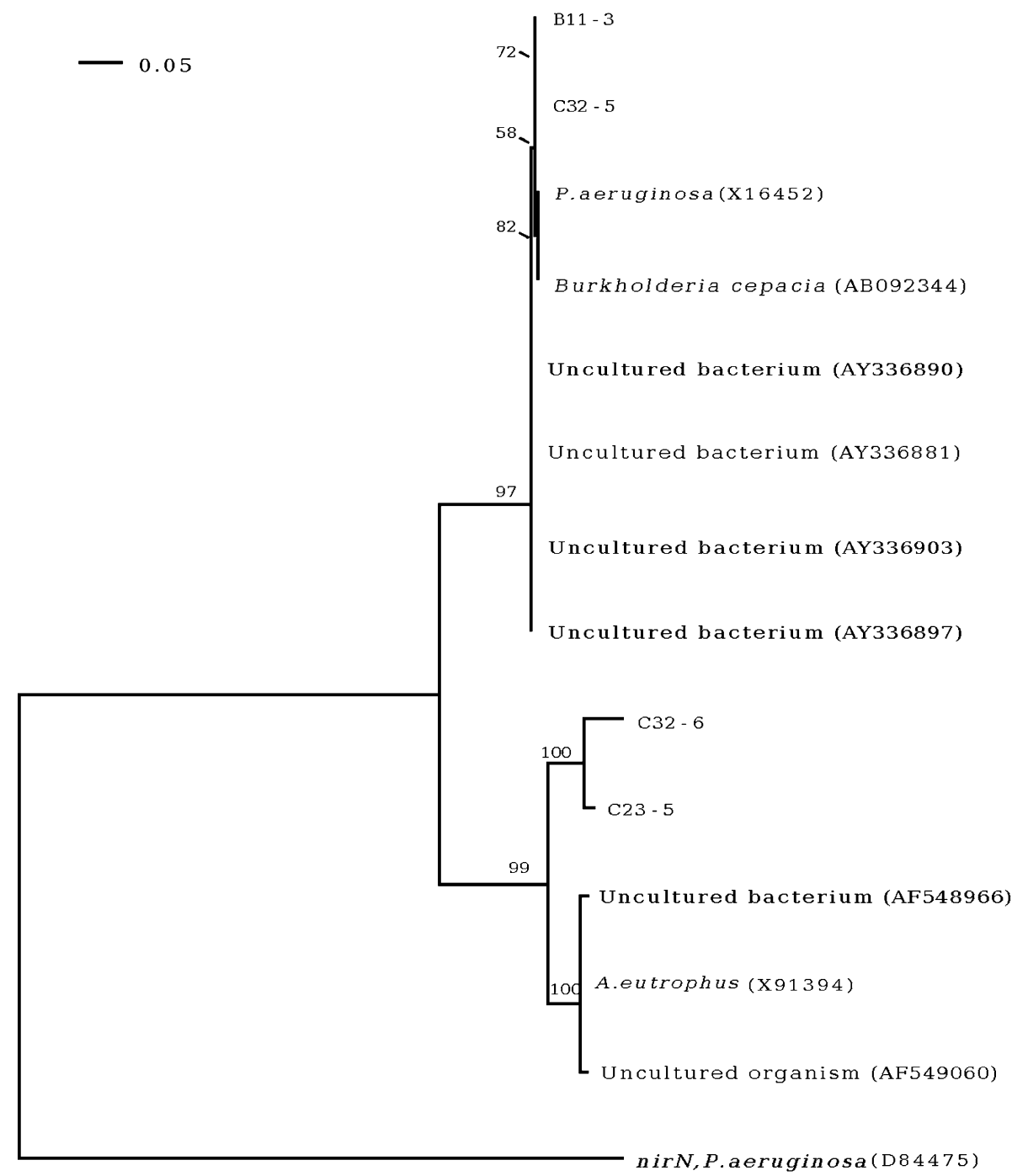

identify genus in our samples since it can be used for general purposes for genus identification in vary groups of environmental bacteria since the originally widely used $16 \mathrm{~S}$ rDNA primers may not be suitable for specific or some small groups of bacteria (see comment in Wang and Qian 2009). Three of the isolates have previously been identified as denitrifiers; Agrobacterium radiobacter, Pseudomonas aeruginosa and Pseudomonas stutzeri (Braker et al. 1998; Hallin and Lindgren 1999; Wang and Skipper 2004). The other three isolates, Burkholderia cepacia, Corynebacterium propinquum and Micrococcus lylae are thus identified as potentially new species of denitrifiers in this study, although alternative means of species identification for conformation, such as phylogenetic analysis of the $16 \mathrm{~S}$ rRNA gene, should be performed. Agrobacterium radiobacter was the dominant species of the denitrifying bacteria from the collected soil, in as much as 6/13 isolates were from this species (Table 1). For the ability to reduce both nitrate and nitrite, two isolates were found to reduce nitrate rapidly (Pseudomonas aeruginosa, B11-3 and Corynebacterium propinquum, A31-18) and one isolate could do it but slowly (Burkholderia cepacia, C22-14). These three isolates did not show any accumulation of nitrite, while the others ten isolates were found to lead to nitrite accumulation and also to reduce nitrate slowly.

DNA extraction, PCR amplification, cloning, sequencing and phylogenetic analysis

The thirteen isolates of denitrifying bacteria were then screened for the presence of the $c d_{1^{-}}$and $\mathrm{Cu}$-nir genes (nirS and nirK, respectively) by PCR amplification using degenerate primers as outlined under the methods section. Five isolates yielded only nirK amplicons (all Agrobacterium radiobacter) while three isolates produced only a nirS amplicon. One isolate (Agrobacterium radiobacter isolate C23-5) apparently had both nirK and nirS genes, and four isolates failed to produce an amplicon for either of the two 
genes (Table 1). For those isolates producing amplicons of the expected size for nirK1F-nirK5R (514 bp) and nirS1F-nirS6R (890 bp), the amplicons were cloned and sequenced.

The partial consensus nirK and nirS nucleotide sequences from all isolates were aligned with the existent nirK and nirS sequences of denitrifying bacteria in the GenBank database. For nirK, this revealed 92-98\% nucleotide sequence identity to the nirK of Pseudomonas aeruginosa (accession no. AY345247), whilst the nirS sequences revealed 92-99\% sequence identity, confirming their likely correct identity as nirK and nirS gene homologues. However, to confirm gene function and structure, complete sequence analysis and protein expression will be performed next. Phylogenetic analysis separated the five isolates which contained nirK into one group, as expected given that they are the same bacterial species (A. radiobacter) from the same region (Fig. 1). However, this clade also included $P$. aeruginosa, suggesting either a highly conserved gene fragment (homoplasy from insufficient informative characters) or recent lateral gene transfer. Interestingly, the nirK sequence of isolate C23-5 which showed a lower sequence identity $(92 \%)$ to the others in this group, although still in the same closely related group as the other $A$. radiobacter and $P$. aeruginosa, was placed distal to these in its own subclade (Fig. 2). Indeed, this close phylogenetic distance for the nirK homologs between $A$. radiobacter and $P$. aeruginosa is not supported by the nirS sequences (Fig. 2), although it is not possible to infer lateral gene transfer over artifacts from homoplasy. The nirS sequences separated into two main groups. The first consisted of isolates B11-3 (Pseudomonas aeruginosa) and C32-5 (Micrococcus lylae), along with existent sequences in the database from uncultured bacteria, B. cepacia and $P$. aeruginosa. The second well separated group consisted of the published sequences plus a different Micrococcus lylae isolate (C32-6) and a sole Agrobacterium radiobacter isolate (C23-5). The two isolates of Micrococcus lylae segregated into the two different well separated groups, again suggesting potential lateral gene transfer but this needs further work for confirmation including molecular species confirmation.

Acknowledgments This research was supported by Rachadapisek Sompoj Fund of Chulalongkorn University, Bangkok, Thailand. We appreciate for Dr. Jittra Piapukiew about molecular technique advice. We would like to thank Dr. Robert Butcher from Publication Counselling Unit, Chulalongkorn University for kindly comments on manuscript English proof.

Open Access This article is distributed under the terms of the Creative Commons Attribution Noncommercial License which permits any noncommercial use, distribution, and reproduction in any medium, provided the original author(s) and source are credited.

\section{References}

Ausubel FM, Brent R, Kingston RE, Moore DD, Seidman JG, Smith JA, Struhl K (2002) Short protocols in molecular biology: a compendium of methods from current protocols in molecular biology, 5th edn. Wiley, New York, pp 2-11

Beishir L (1996) Microbiology in practice: a self-instructional laboratory course, 6th edn. Harper Collins College Publishers, New York, pp 318-319

Braker G, Fesefeldt A, Witzel KP (1998) Development of PCR primer systems for amplification of nitrite reductase genes (nirK and $n i r S)$ to detect denitrifying bacteria in environmental samples. Appl Environ Microbiol 64:3769-3775

Braker G, Zhou J, Wu L, Devol AH, Tiedje JM (2000) Nitrite reductase genes (nirK and nirS) as functional markers to investigate diversity of denitrifying bacteria in Pacific Northwest marine sediment communities. Appl Environ Microbiol 66:2096-2104

Hallin S, Lindgren PE (1999) PCR detection of genes encoding nitrite reductase in denitrifying bacteria. Appl Environ Microbiol 65:1652-1657

Henry S, Baudoin E, Lopez-Gutiérrez JC, Martin-Laurent F, Brauman A, Phillipot L (2004) Quantification of denitrifying bacteria in soil by nirK gene targeted real-time PCR. J Microbiol Methods 59:327-335

Heylen K, Gevers D, Vanparys B, Wittebole L, Geets J, Boon N, De Vos P (2006) The incidence of nirS and nirK and their genetic heterogeneity in cultivated denitrifiers. Environ Microbiol 8(11):2012-2021

Oakley BB, Francis CA, Robert KJ, Fuchman CA, Srinvasan S, Staley JT (2007) Analysis of nitrite reductase (nirK and nirS) genes and cultivation reveal depauperate community of denitrifying bacteria in the Black Sea suboxic zone. Environ Microbiol 9(1):118-130

Priemé A, Braker G, Tiedje JM (2002) Diversity of nitrite reductase (nirK and nirS) gene fragment in forested upland and wetland soil. Appl Environ Microbiol 68:1893-1900

Rich JJ, Heichen RS, Bottomley PJ, Cromack K Jr, Myrold DD (2003) Community composition and functioning of denitrifying bacteria from adjacent meadow and forest soils. Appl Environ Microbiol 69:5974-5982

Santoro AE, Boehm AB, Francis CA (2006) Denitrifier community composition along a nitrate and salinity gradient in a coastral aquifer. Appl Environ Microbiol 72(3):2102-2109

Wang Y, Qian P-Y (2009) Conservative fragments in bacterial 16S rRNA genes and primer design for $16 \mathrm{~S}$ ribosomal DNA amplicons in metagenomic studies. PLoS ONE 4(10):7401-7409

Wang G, Skipper HD (2004) Identification of denitrifying rhizobacteria from bentgrass and bermudagrass golf greens. J Appl Microbiol 97:827-837

Wistreich GA, Lechtman MD (1988) Laboratory exercises in microbiology, 6th edn. Macmillan, New York, pp 220-221

Zumft WG (1997) Cell biology and molecular basis of denitrification. Microbiol Mol Biol Rev 61:533-616 